\title{
膠原病関連肺高血圧症の治療
}

釜田康行，岩本雅弘，䇾田清次

\section{Treatment of pulmonary hypertension associated with connective tissue disease}

\author{
Yasuyuki Kamata, Masahiro Iwamoto, Seiji Minota \\ Division of Rheumatology and Clinical Immunology, Department of Medicine, Jichi Medical University
}

(Received September 28, 2008)

summary

Pulmonary hypertension is the most ominous complication of connective tissue diseases and its treatment has been a big challenge to clinicians. Vasodilators including epoprostenol (prostacyclin), bosentan (endothelin-receptor antagonist), and a sildenafil (phosphodiesterase type 5 inhibitor) have recently become available in Japan. These vasodilators may improve exercise tolerance, hemodynamics, activities of daily life, and the life span. In this article, we review an endothelin-receptor antagonist and phosphodiesterase type 5 inhibitor recently approved as treatment modalities for pulmonary hypertension in Japan.

Key words_ pulmonary hypertension; endothelin receptor antagonist; phosphodiesterase type 5 inhibitor

抄 録

肺高血圧症は，稀な疾患ではあるが進行性かつ難治性で治療に難渋する．膠原病でもしばしば肺高血圧症の合併 を認めるが，その予後は極めて不良である。しかし，近年プロスタサイクリンであるエポプロステノールをはじ め，エンドセリン受容体拮抗薬であるボセンタンや，ホスホジエステラーゼ-5 阻害薬であるシルデナフィルな ぞ, 強力な血管拡張作用を有する薬剤が本邦でも使用できるようになった。これらの薬剤は運動耐容能をはじめ, 循環動態, ADLの改善, さらには肺高血圧症の予後の改善が大いに期待できる薬剤である. 本稿では肺高血圧症 の治療薬のうち, 最近本邦で認可されたエンドセリン受容体拮抗薬とホスホジエステラーゼ-5 阻害薬について解 説する.

\section{I. はじめに}

肺高血圧症とは，肺動脈圧の上昇を認める病態の 総称であり，その原因は多岐にわたる。2003 年 6 月にイタリアのベニスで開催された第 3 回肺高血圧 症国際シンポジウムで，これまで肺高血圧症の臨床 分類であったエビアン分類が改定され，新たにベニ ス分類が提唱された．このべニス分類では，(1)肺動 脈性肺高血圧症，(2)左心性疾患に伴う肺高血圧症， (3)肺疾患および/または低酸素血症に伴う肺高血圧 症，(4)慢性血栓性および/または塞栓性疾患におけ る肺高血圧症, (5)その他の肺高血圧症（サルコイ ドーシス，ヒスチオサイトーシス $\mathrm{X}$ ，リンパ管腫 症，肺血管の圧迫など）の5つに大別された．膠原 病に合併する肺高血圧症は，ベニス分類で肺動脈性

自治医科大学内科学講座アレルギー膠原病学部門
肺高血圧症の中に細分類された1).ただし，膠原病 に合併する肺高血圧症は, 原発性肺高血圧症と同様 の肺動脈性肺高血圧症以外にも, 強皮症などに合併 する間質性肺炎に伴う肺高血圧症, 抗リン脂質抗体 症候群などに合併する肺血栓症に伴う肺高血圧症も 発症し得る。

膠原病に伴う肺高血圧症の合併率には，本邦でも いくつかの報告があるが，代表的なものとして 2003 年の全身性自己免疫疾患に打碓治性病態 の診断と治療法に関する研究報告によると, 混合性 結合組織病で $16.0 \%$, 強皮症で $11.4 \%$, 全身性工 リテマトーデスで $9.3 \%$, 多発性筋炎/皮膚筋炎で 1.5\%であった2).

原発性肺高血圧症の定義は, 安静臥床時の平均 肺動脈圧が $25 \mathrm{mmHg}$ 以上, または運動時の平均 肺動脈圧が $30 \mathrm{mmHg}$ 以上で, 肺動脈楔入圧が 12 $\mathrm{mmHg}$ 以下である ${ }^{3)}$. 診断は, 臨床症状（労作時呼 
吸困難，易疲労感，動悸，胸痛など），身体所見 (IIp 音の元進, 頸静脈の怒張, 下腿浮腫, 腹水な ぞ), 血液検查 (動脈血液ガス, 尿酸, BNP など), 心電図（右室肥大，肺性 P 波など)，心エコー（三 尖弁逆流など），胸部 $\mathrm{X}$ 線（左第 2 弓の突出，心拡 大, 中枢肺動脈の拡張など), 胸部 $\mathrm{CT}$, 胸部 MRI, 肺シンチグラム, 肺動脈造影, 右心カテー テル検査, 肺生検などにより行われる.

肺高血圧症は，極めて予後不良な疾患であり，膠 原病でも死因の上位に肺高血圧症があげられてい る.肺高血圧症により上昇した肺循環抵抗は広範囲 な心蔵の器質的変化をもたらし，やがては右心不全 に至り，患者の運動耐容能を著しく低下させる．ま た, 心不全や心蔵の器質的変化は, 時に致命的な不 整脈を誘発し，しばしば突然死の原因となっている.

肺高血圧症の診断, 打よび酸素療法, 抗凝固療 法, ステロイド薬, カルシウム拮抗薬, プロスタサ イクリンによる治療については本会誌の既報にて詳 細に示されているため4), 本稿では肺高血圧症の治 療薬として新たに本邦で認可されたエンドセリン受 容体拮抗薬とホスホジエステラーゼ-5（PDE-5） 阻害薬について解説する.

\section{II. エンドセリン受容体拮抗薬}

\section{1. 作用機序}

エンドセリン -1 は，本邦で発見されたペプチド であり, 強力かつ持続的な肺血管収縮作用と血管平 滑筋の増殖作用を有する ${ }^{5,6)}$. 肺高血圧症の患者で は健常者と比較して血漿中エンドセリン -1 の濃度 が上昇している7)。 また，肺血管内皮細胞でのエン ドセリン -1 の発現が増加して抢り，その程度と肺 高血圧症の重症度との間には相関関係がみられるこ とから，エンドセリン -1 が肺高血圧症の病態形成 に関与していると考えられている8

エンドセリン（ET）受容体にはエンドセリン -1 に選択的な（親和性が強い） $\mathrm{ET}_{\mathrm{A}}$ 受容体と, 非選 択的 $\mathrm{ET}_{\mathrm{B}}$ 受容体がある。血管系においては, $\mathrm{ET}_{\mathrm{A}}$ 受容体は血管平滑筋細胞に発現しており，エンドセ リン -1 が結合すると血管平滑筋細胞内のカルシウ ムイオン濃度を上昇させることにより，血管平滑筋 を収縮させて血管収縮に至る9,10)， $\mathrm{ET}_{\mathrm{B}}$ 受容体は主 に血管内皮細胞に存在し，血管拡張物質の放出に関 与しているが，血管平滑筋にも発現しており血管収 縮にも関わっていると考えられている11,12)。

エンドセリン受容体拮抗薬としては, $\mathrm{ET}_{\mathrm{A}}$ 受容
体と $\mathrm{ET}_{\mathrm{B}}$ 受容体の両者をブロックするボセンタ ン, 選択的に $\mathrm{ET}_{\mathrm{A}}$ 受容体をブロックする ambrisen$\tan$ や sitaxsentan (本邦では未承認) などが開発さ れている．エンドセリンによる血管収縮作用を抑制 するためには, 両受容体をブロックすることが必要 であることを示唆する報告もあるが13)，実際の肺高 血圧症の患者に対して $\mathrm{ET}_{\mathrm{A}}$ と $\mathrm{ET}_{\mathrm{B}}$ の両受容体をブ ロックした場合と, $\mathrm{ET}_{\mathrm{A}}$ 受容体のみをブロックし た場合ではどちらがより効果的であるかは, 現時点 では議論を残すところである。

\section{2. ボセンタン}

2001 年に World Health Organization (WHO) 機 能分類（表 1）III の肺高血圧症の患者 32 例（原発 性肺高血圧症, 強皮症に伴う肺高血圧症）を対象 に, 無作為化二重盲検試験が行われた. ボセンタン は最初の 4 週間 $125 \mathrm{mg} /$ day（62.5 mg を 1 日 2 回） で投与開始され，その後 $250 \mathrm{mg} /$ day $(125 \mathrm{mg}$ を 1 日 2 回）に増量された。その結果，12 週間後には 6 分間歩行試験, 心係数, 肺血管抵抗において有意な 改善が見られた。 また，WHO 機能分類の改善がみ られ, 症状悪化 (clinical worsening) を緩徐にする 効果が認められた ${ }^{14)}$.

また, 2002 年には, WHO 機能分類 III に加え機 能分類 IV の重症肺高血圧症の患者 213 例（原発性 肺高血圧症, 強皮症または全身性エリテマトーデス に伴う肺高血圧症）を対象に, プラセボ群, ボセン タン $125 \mathrm{mg} / \mathrm{day}(62.5 \mathrm{mg}$ を 1 日 2 回）投与群, ボ センタン $250 \mathrm{mg} /$ day ( $125 \mathrm{mg}$ を 1 日 2 回) 投与群 の 3 群で無作為化二重盲検試験が行われた. その結 果, 16 週後には 6 分間歩行試験で $125 \mathrm{mg} / \mathrm{day}$ 投与 群および $250 \mathrm{mg} /$ day 投与群ともにプラセボ群に比 して有意に歩行距離の延長を認めた。 また, Borg dyspnea index, WHO 機能分類の改善や症状悪化を 緩徐にする効果が認められた15)。この結果より, ボ センタンはより重症な肺高血圧症に対しても有効で あることが証明された。

さらに 2008 年には, WHO 機能分類 II の早期ま たは軽症の肺高血圧症患者（原発性肺高血圧症, 先 天性疾患に伴う肺高血圧症, HIV に伴う肺高血圧 症, 膠原病に伴う肺高血圧症）185 例を対象に, 無 作為化二重盲検試験が行われた（EARLY 試験）. ボセンタンは最初の 4 週間 $125 \mathrm{mg} /$ day $(62.5 \mathrm{mg}$ を 1 日 2 回）で投与開始され，その後 $250 \mathrm{mg} /$ day （125 mg を 1 日 2 回）に増量された（体重が軽いな 
表 1 肺高血圧症の機能分類

\begin{tabular}{|c|c|c|}
\hline & NYHA 心機能分類 & WHO 肺高血圧症機能分類 \\
\hline Class I & 通常の身体活動では無症状. & $\begin{array}{l}\text { 身体活動に制限のない肺高血圧症患者. } \\
\text { 普通の身体活動では呼吸困難や疲労, 胸痛や失神など生じない. }\end{array}$ \\
\hline Class II & $\begin{array}{l}\text { 通常の身体活動で症状発現, 身体活動がやや } \\
\text { 制限される. }\end{array}$ & $\begin{array}{l}\text { 身体活動に軽度の制限のある肺高血圧症患者. } \\
\text { 安静時には自覚症状がない. 普通の身体活動で呼吸困難や疲労, } \\
\text { 胸痛や失神などが起こる. }\end{array}$ \\
\hline Class III & $\begin{array}{l}\text { 通常以下の身体活動で症状発現，身体活動が } \\
\text { 著しく制限される. }\end{array}$ & $\begin{array}{l}\text { 身体活動に著しい制限のある肺高血圧症患者. } \\
\text { 安静時に自覚症状がない. } \\
\text { 普通以下の軽度の身体活動で呼吸困難や疲労, 胸痛や失神などが } \\
\text { 起こる. }\end{array}$ \\
\hline Class IV & どんな身体活動あるいは安静時でも症状発現. & $\begin{array}{l}\text { ぞんな身体活動もすべて苦痛となる肺高血圧症患者. } \\
\text { これらの患者は右心不全の症状を表している. } \\
\text { 安静時にも呼吸困難および/または疲労がみられる. } \\
\text { どんな身体活動でも自覚症状の増悪がある. }\end{array}$ \\
\hline
\end{tabular}

NYHA : New York Heart Association WHO : World Health Organization

どの理由で一部の症例は $125 \mathrm{mg} /$ day を継続され た)。その結果，6 分間歩行試験，肺血管抵抗の改 善，NT-pro-BNP の低下，抢よび症状悪化を緩徐に するなどの効果が認められた16).

2007 年の改定 American College of Chest Physicians（ACCP）ガイドラインではボセンタンによる 治療を WHO 機能分類 III とIV に扔いて推奨度 A で最も推奨される薬荗としている17)。しかし上記 EARLY 試験の結果より，ボセンタンが WHO 機能 分類 II の早期または軽症肺高血圧症にも有用であ ることが証明された。そのため，ボセンタンは早期 から重症まで肺高血圧症治療の第 1 選択薬としても 考慮すべき薬剤であると考えられる.

ボセンタンの副作用としては，血管拡張に伴う頭 痛やほてりの他, 肝機能障害が見られることがある ため，定期的な肝機能検査を必要とする。また， ワーファリンの効果減弱をしばしば認めるため, ワーファリン併用時には注意が必要である18)。シク ロスポリンとの併用は肝の代謝酵素が同じである理 由からシクロスポリンの併用が禁忌となっている. そのため，シクロスポリンを使用する機会が多い膠 原病に伴う肺高血圧症では注意を要する.

\section{3. アンブリセンタン (ambrisentan) , シタクス センタン (sitaxsentan)}

ambrisentan と sitaxsentan は $\mathrm{ET}_{\mathrm{A}}$ 受容体拮抗薬 であり, 本邦では未承認の薬剤である.

ambrisentan は，2007 年に WHO 機能分類 II（38 \%)，III（55\%）を主体に肺高血圧症の患者 394 例
（原発性肺高血圧症，強皮症または全身性エリテマ トーデスに伴う肺高血圧症）を対象に, 無作為化二 重盲検試験が行われた。その結果, 12 週後に 6 分 間歩行試験に抢いて ambrisentanを 1 日 1 回 2.5 $\mathrm{mg}, 5 \mathrm{mg}, 10 \mathrm{mg}$ のいずれの投与量においても, プ ラセボ投与群と比較して有意に延長し, 投与前と比 較して血漿 BNP の低下を認めた。また, 肝機能障 害の出現頻度は低かった ${ }^{19)}$.

sitaxsentan は, 2005 年に原発性肺高血圧症, 先 天性疾患打よび膠原病に伴う肺高血圧症の患者 247 例を対象に, sitaxsentan $50 \mathrm{mg}$ 投与群と $100 \mathrm{mg}$ 投 与群, ボセンタン $125 \mathrm{mg}$ 投与群, プラセボ群の 4 群で無作為化二重盲検試験が行われた。その結果,

1 日 1 回 $100 \mathrm{mg}$ の sitaxsentan 投与群で, 18 週後に 6 分間歩行試験および WHO 機能分類で, ボセンタ ン $125 \mathrm{mg}$ 投与群と同等の改善を認めた。 また, 肝 機能障害はボセンタン投与群よりも出現頻度は低か った ${ }^{20)}$.

これらの結果より, 肺高血圧症に対して $\mathrm{ET}_{\mathrm{A}}$ 受 容体のみをブロックしても， $\mathrm{ET}_{\mathrm{A}}$ と $\mathrm{ET}_{\mathrm{B}}$ 受容体の 両方をブロックした場合と同等の効果が得られ，副 作用として肝機能障害の出現頻度が低いことから有 用な薬剂である可能性が示唆された。

\section{PDE-5 阻害薬}

\section{1. 作用機序}

性的刺激は中枢神経系の興奮を介して血管内皮細 胞や海綿体神経終末から一酸化窒素（NO）を放出 させる。この NO は，血管拡張作用を有するが， 
性的刺激以外にもブラジキニンなどの化学的刺激や ずり応力などの物理的刺激によっても産生される. 血管内皮細胞で産生された NO は血管平滑筋細胞 に作用して，グアニル酸シクラーゼを活性化させ， GTP から cGMP を生成する。 cGMP は cGMP 依 存性プロテインキナーゼを活性化し，血管平滑筋細 胞の Ca チャネルを介する細胞外からの Ca イオン の流入を抑制するなどして細胞内の Caイオン濃度 を低下させる．血管平滑筋細胞内の Ca イオン濃度 の低下により, アクチンーミオシン複合体が解離 し, 血管平滑筋は弛緩し拡張する. その後, cGMP は速やかにPDE-5による加水分解を受け， 5'GMP に分解されることにより，血管拡張は終息する。こ の PDE-5 を阻害することにより cGMP の加水分解 が抑制されるため，NOによる血管拡張作用は持 続・増強する。PDE-5 は肺組織や陰茎海綿体に豊 富に存在しているため, PDE-5 阻害薬の全身投与 によっても肺血管選択性が得られると考えられてい $ろ^{21)}$.

PDE-5 阻害薬は血管拡張に伴う体血圧の低下が 懸念されるが，シルデナフィルの場合，収縮期血圧 で 8〜 $10 \mathrm{mmHg}$, 拡張期血圧で 5〜 $6 \mathrm{mmHg}$ とわず かな血圧低下が認められるのみである22).

\section{2. シルデナフィル}

現在, 肺高血圧症に認可されている唯一の PDE5 阻害薬である. 2005 年に WHO 機能分類 II IV の肺高血圧症（原発性肺高血圧症，膠原病および先 天心疾患に伴う肺高血圧症）の患者 278 例を対象 に, 無作為化二重盲検試験が行われた. その結果, シルデナフィル $20 \mathrm{mg} /$ day 投与群, $40 \mathrm{mg} /$ day 投 与群, および $80 \mathrm{mg} / \mathrm{day}$ 投与群において 12 週後に プラセボと比較して有意に 6 分間歩行距離が延長し た.しかし，これら用量の異なるシルデナフィルを 投与した 3 群の間に有意差は認められなかった。 た，平均肺動脈圧，肺血管抵抗，WHO 機能分類の 改善, 症状悪化を緩徐にするなどの効果が認められ た23).

ボセンタンとシルデナフィルとの併用療法につい ては，論議があるところである，ボセンタン単独治 療では効果不十分な症例にシルデナフィルを追加投 与したところ，原発性肺高血圧症の患者においては 6 分間歩行距離抢よび WHO 機能分類の改善を認め たが，強皮症に伴う肺高血圧症では改善を認めなか ったという報告がある ${ }^{24)}$ 。た，10 名の肺高血圧
症の患者に対して, ボセンタン $125 \mathrm{mg} /$ day とシル デナフィル $100 \mathrm{mg} / \mathrm{day}$ を併用したところ, シルデ ナフィルの AUC が 50\%減少し，ボセンタンを 250 $\mathrm{mg} /$ day に増量することによりシルデナフィルの AUC がさらに減少し, 両者の併用により有意にシ ルデナフィルの血漿濃度が減少することが報告され ている25). 肺高血圧症に対して, シルデナフィルを 単独投与して血中濃度を十分に上昇させたほうが良 いのか, ボセンタンと併用して両者の血管拡張作用 を得たほうが良いのかについてのエビデンスはな い.したがって, シルデナフィル単独投与群, ボセ ンタン単独投与群, シルデナフィルとボセンタンの 併用群の 3 群間での比較調查が期待される.

シルデナフィルは, 2007 年の改定 ACCP ガイド ラインでは WHO 機能分類 II とIII において推奨 度 $\mathrm{A}$ の最も推奖される薬剤とされているが, WHO 機能分類 IV では推奨度 $\mathrm{C}$ と低く推奨されてい る17). しかし, シルデナフィルには投与後短時間で 肺動脈を速やかに拡張させる効果があることから （図 1), 筆者らは WHO 機能分類 IV に相当する肺 高血圧症の急性増悪期には, reliever としてシルデ ナフィルを投与し，急性期を脱する使用方法もある と考えている26.

シルデナフィルの副作用としては, 本邦の市販後 調査によると, ほてりが $3.17 \%$, 頭痛が $1.08 \%$, 動悸が $0.41 \%$ で認められている. また, 眼の副作 用（彩視症, 羞明など）は $0.25 \%$ であり,これは 眼の網膜に豊富に存在する PDE-6をもシルデナフ ィルが阻害してしまうためではないかと考えられて いる27)。また， 2007 年 10 月に U.S. Food and Drug

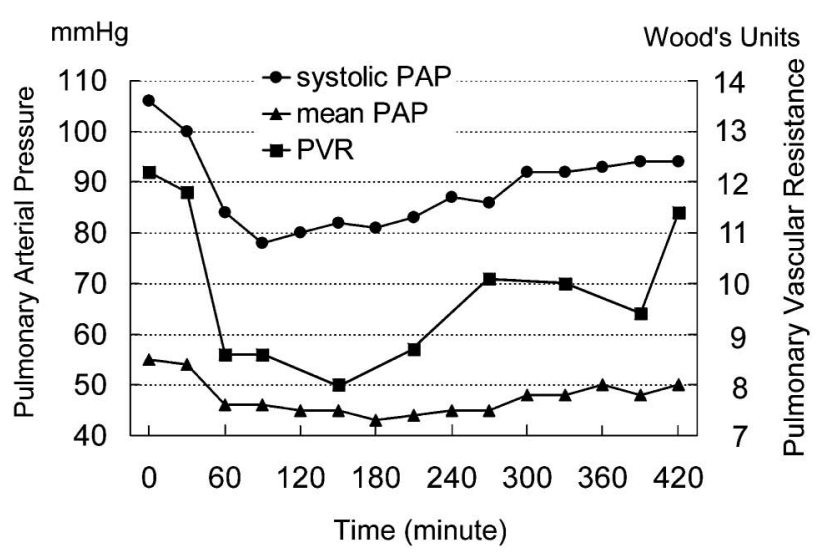

図 1

図 1 は, シルデナフィル $50 \mathrm{mg}$ を単回投与した後 420 分 の間, 収縮期肺動脈圧, 平均肺動脈圧, および肺血管抵抗の 変化を経時的に示した図である。 
Administration（米国 FDA）より，シルデナフィ ルをはじめとする PDE-5 阻害薬の使用で聴力の低 下や聴力を失う恐れがあるという警告が発表された。

PDE-5 阻害薬と聴力障害との明確な因果関係抢よ び発症機序についてはまだ不明であるが，PDE-5 阻害薬の使用後に突然聴力低下や聴力喪失が出現し た事例が，1996 年から米国 FDA に 29 件報告され ている.そのため, 米国 FDA では PDE-5 使用に より聴力の低下や耳鳴りが出現した場合には，ただ ちに使用を中止するように注意を喚起している.

\section{3. バルデナフィル, タダラフィル}

本邦では，PDE-5 阻害薬としてシルデナフィル 以外にバルデナフィルとタダラフィルが ED 治療薬 として認可されている。それぞれの PDE-5 阻害薬 には特徵があり, バルデナフィルはシルデナフィル と同等の効果持続時間であるが，PDE ファミリー の中で PDE-5 に対してシルデナフィルよりも高い 選択性を有している。一方タダラフィルは，EDに おけるデータを参考にすると，シルデナフィルとバ ルデナフィルは効果の持続時間が約 4 時間であるの に対して, タダラフィルは約 36 時間と極めて長 く，食事の影響を受けないという特徵がある (表 2) ${ }^{28)}$ 。 また, タダラフィルでは, 副作用として 頭痛 $11.3 \%$, 潮紅・ほてり $8.6 \%$ に加えて, 消化不 良 $2.3 \%$ が認められており（臨床試験結果より）, シルデナフィルやバルデナフィルとは異なっていた.

3 種類の PDE-5 阻害薬の薬物動態を比較したも のを表 3 に示した ${ }^{29)}$. また，ヒト遺伝子組換え PDE アイソザイムに対するシルデナフィル，バル デナフィル, タダラフィルの選択性について表 4 に 示した ${ }^{31}$. PDE-5 阻害作用と比較して PDE-6 阻害
表 3 PDE-5 阻害薬の薬物動態の比較

\begin{tabular}{crcc}
\hline \hline & $\begin{array}{c}\text { シルデナ } \\
\text { フィル } \\
100 \mathrm{mg}\end{array}$ & $\begin{array}{c}\text { バルデナ } \\
\text { フィル } \\
20 \mathrm{mg}\end{array}$ & $\begin{array}{c}\text { タダラフィル } \\
20 \mathrm{mg}\end{array}$ \\
\hline $\mathrm{Cmax}(\mathrm{ng} / \mathrm{mL})$ & 560 & 209 & 378 \\
\hline $\mathrm{Tmax}(\mathrm{h})$ & 0.8 & 0.7 & 2.0 \\
\hline $\mathrm{T} 1 / 2(\mathrm{~h})$ & 3.7 & 3.9 & 17.5 \\
\hline $\mathrm{AUC}(\mathrm{ng} \cdot \mathrm{h} / \mathrm{mL})$ & 1,685 & 74.5 & 8,066 \\
\hline & & \multicolumn{3}{c}{ (文献 29 より改変) }
\end{tabular}

表 4 ヒトPDE アイソザイムに対するタダラフィル，シル デナフィル, バルデナフィルの選択性

\begin{tabular}{|c|c|c|c|c|}
\hline PDE family & gene & タダラフィル & $\begin{array}{l}\text { シルデナ } \\
\text { フィル }\end{array}$ & $\begin{array}{l}\text { バルデナ } \\
\text { フィル }\end{array}$ \\
\hline \multirow{3}{*}{ PDE-1 } & a & 20,000 & 290 & 630 \\
\hline & $\mathrm{b}$ & 21,000 & 1,100 & 5,000 \\
\hline & c & 11,000 & 110 & 460 \\
\hline PDE-2 & $\mathrm{a}$ & 49,000 & 19,000 & 72,000 \\
\hline \multirow{2}{*}{ PDE-3 } & $\mathrm{a}$ & 38,000 & 12,000 & 7,700 \\
\hline & $\mathrm{b}$ & 18,000 & 17,000 & 15,000 \\
\hline \multirow{4}{*}{ PDE-4 } & $\mathrm{a}$ & 30,000 & 6,000 & 46,000 \\
\hline & $\mathrm{b}$ & 22,000 & 5,800 & 33,000 \\
\hline & $\mathrm{c}$ & 23,000 & 5,200 & 34,000 \\
\hline & d & 13,000 & 3,600 & 16,000 \\
\hline $\mathrm{PDE}-5$ & & 1 & 1 & 1 \\
\hline PDE-6 & & 780 & 7 & 3 \\
\hline PDE-7 & $\mathrm{a}$ & 47,000 & 22,000 & 200,000 \\
\hline PDE-8 & $\mathrm{a}$ & 30,000 & 19,000 & 310,000 \\
\hline PDE-9 & $\mathrm{a}$ & 19,000 & 540 & 3,600 \\
\hline PDE-10 & $\mathrm{a}$ & 9,000 & 3,100 & 12,000 \\
\hline PDE-11 & $\mathrm{a}$ & 14 & 1,500 & 640 \\
\hline
\end{tabular}

表 2 PDE-5 阻害薬の対比

\begin{tabular}{|c|c|c|c|c|c|c|}
\hline & \multicolumn{2}{|c|}{ シルデナフィル } & \multicolumn{2}{|c|}{ バルデナフィル } & \multicolumn{2}{|c|}{ タダラフィル } \\
\hline 量 & \multicolumn{2}{|c|}{$25 \mathrm{mg} / 50 \mathrm{mg}$} & \multicolumn{2}{|c|}{$5 \mathrm{mg} / 10 \mathrm{mg} / 20 \mathrm{mg}$} & \multicolumn{2}{|c|}{$5 \mathrm{mg} / 10 \mathrm{mg} / 20 \mathrm{mg}$} \\
\hline 効果の持続時間 & \multicolumn{2}{|c|}{ 約 4 時間 } & \multicolumn{2}{|c|}{ 約 4 時間 } & \multicolumn{2}{|c|}{ 約 36 時間 } \\
\hline 食事の影 響 & \multicolumn{2}{|c|}{ 高脂肪食にて Cmax が低下する } & \multicolumn{2}{|c|}{ 適度な脂肪食なら可 } & \multicolumn{2}{|c|}{ 吸収速度に影響なし } \\
\hline 有 害 事 象 & $\begin{array}{l}\text { 頭痛 } \\
\text { ほてり } \\
\text { 視覚障害 }\end{array}$ & $\begin{array}{r}12.7 \% \\
10.2 \% \\
1.9 \%\end{array}$ & $\begin{array}{l}\text { 頭痛 } \\
\text { ほてり } 1 \\
\text { 鼻閉 } \\
\text { 心悸え進 }\end{array}$ & $\begin{array}{r}5.6 \% \\
15.7 \% \\
3.0 \% \\
3.0 \%\end{array}$ & $\begin{array}{l}\text { 頭痛 } \\
\text { ほてり } \\
\text { 潮紅 } \\
\text { 消化不良 }\end{array}$ & $\begin{array}{r}1.3 \% \\
3.5 \% \\
5.1 \% \\
2.3 \%\end{array}$ \\
\hline
\end{tabular}

市 販 年 度

1999 年

2004 年

2007 年 
作用はシルデナフィルは $1 / 7$, バルデナフィルは $1 /$ 3, タダラフィルは $1 / 780$ であり, 眼の副作用に対 する危険性は低いと考元られている．PDE-5 阻害 薬使用による眼に対する副作用は，PDE-5 阻害薬 が網膜に存在する PDE-6 までをも阻害すると，網 膜中の cGMP が増加して Na イオンの透過性が高 まるため，本来過分極性に生じるはずの光応答が影 響を受け, 青視症, 霧視, 光感受性上昇などの視覚 異常をきたしてしまうと考えられている27,30). PDE-5 阻害作用と比較した PDE-1〜PDE-11 の阻 害作用は, シルデナフィルに比較してバルデナフィ ル, タダラフィルは小さく, PDE-5 に対する高い 選択性を有している31).

血管拡張作用が長時間持続するタダラフィルは， 肺高血圧症に対してもより有用な薬剤である可能性 があり, 肺高血圧症に対する適応が期待される.

\section{IV. 肺高血圧症の予後}

約 20 年前の調査によると, 本邦に抢ける膠原病 に合併した肺高血圧症の診断から死亡までの期間 は, 混合性結合組織病で平均 0.75 年, 全身性エリ テマトーデスで 1.57 年, 強皮症で 2.62 年であり, 極めて予後不良であった

しかし，エポプロステノールの登場により，その 予後は著しく改善された。本邦のエポプロステノー ル市販後調查結果によると, 原発性肺高血圧症の 1 年, 3 年, 5 年生存率はそれぞれ $79.9 \%, 68.1 \%$, $59.8 \%$ であり, 膠原病に伴う肺高血圧症の 1 年, 3 年，5 年生存率はそれぞれ $64.8 \% ， 60.2 \% ， 54.7 \%$ と原発性に比較して膠原病性のほうが 1 年生存率は $15 \%$ 程低かったものの，5年生存率がともに $50 \%$ を 超えており，その予後に明らかな改善が認められ た ${ }^{33)}$.

また，海外の報告では，NYHA 機能分類（表 1） III とIVの 178 名の原発性肺高血圧症に対してエ ポプロステノールを投与したところ，その 1 年， 3 年，5年生存率は，それぞれ $85 \% ， 63 \% ， 55 \%$ であ った。これに対してエポプロステノールを投与して おらず，NYHA 機能分類を適合させた 135 名の原 発性肺高血圧症の過去の類似対照群（historical control group）の 1 年, 3 年, 5 年生存率は, それ ぞれ $58 \% ， 33 \% ， 28 \%$ ありエポプロステノール 投与群に有意な生存率の改善が認められた ${ }^{34)}$.

肺高血圧症を重症度別に分類した場合の 1 年, 3 年, 5 年生存率は, NYHA 機能分類 III ではそれぞ
れ 89.7\%，80.2\%，69.9\%，NYHA 機能分類 IV で は，それぞれ $60.3 \%, 49.0 \%, 41.3 \%$ あり， NYHA 機能分類 IV では, 生存率は低く治療の難し さが伺われる33).

\section{V. おわりに}

近年, 本邦でもエンドセリン受容体拮抗薬, PDE -5 阻害薬が肺高血圧症に対して認可されたこ とから, 肺高血圧症の治療に際しての選択肢が大幅 に増加した。これまでの臨床研究は主に短期間の影 響を見たものが多く, 肺動脈性肺高血圧症はすでに 血管の器質的変化を生じたものが多いことから, エ ポプロステノールのように 1 年, 3 年, 5 年あるい はそれ以上の長期予後を改善するのかどうかの調査 結果が待たれる.

\section{文献}

1) Rubin LJ, Abman SH, Ahearn GS, et al.: Diagnosis of management of pulmonary arterial hypertension: ACCP based clinical practice guidelines. Chest. 126: 1S-92S, 2004.

2）吉田俊治, 深谷修作 : 膠原病性肺高血圧症の 頻度と病態の解析 厚生労働科学研究費補助 金免疫アレルギ一疾患予防・治療研究事業全 身性自己免疫疾患に抢ける難治性病態の診断 治療法に関する研究. 平成 15 年度総括. 分担 研究報告書. 40-43, 2004.

3) Rich S, Dantzker DR, Ayres SM, et al.: Primary pulmonary hypertension. A national prospective study. Ann Intern Med. 107: 216-223, 1987.

4）遠藤平仁, 田中住明, 坂井美保: 肺高血圧症. Jpn J Clin Immunol. 27: 127-136, 2004.

5) Yanagisawa $M$, Kurihara $H$, Kimura $S$, et al.: A novel potent vasoconstrictor peptide produced by vascular endothelial cells. Nature. 332: 411415, 1988.

6) Dubin D, Pratt RE, Dzau VJ: Endothelin, a potent vasoconstrictor, is a vascular smooth muscle mitogen. J Vas Med Biol. 1: 150-154, 1989.

7) Stewart DJ, Levy RD, Cernacek P, et al.: Increased plasma endothelin-1 in pulmonary hypertension: marker or mediator of disease. Ann Intern Med. 114: 464-469, 1991.

8) Giaid A, Yanagisawa M, Langleben D, et al.: Expression of endothelin-1 in the lungs of patients with pulmonary hypertension. $N$ Engl $J$ 
Med. 328: 1732-1739, 1993.

9) Simonson MS, Dunn MJ: Cellular signaling by peptides of the endothelin gene family. FASEB J. 4: 2989-3000, 1990.

10) Sakurai T, Yanagisawa M, Masaki T: Molecular characterization of endothelin receptors. Trends Pharmacol Sci. 13: 103-108, 1992.

11) Masaki T, Miwa S, Sawamura T, et al.: Subcellular mechanisms of endothelin action in vascular system. Eur J Pharmacol. 375: 133-138, 1999.

12) Kim NH, Rubin LJ: Endothelin in health and disease: endothelin receptor antagonists in the management of pulmonary artery hypertension. J Cardiovasc Pharmacol Ther. 7: 9-19, 2002.

13) Sato K, Oka M, Hasunuma K, et al.: Effects of separate and combined ETA and ETB blockade on ET-1-induced constriction in perfused rat lungs. Am J Physiol. 269: L668-672, 1995.

14) Channick RN, Simonneau G, Sitbon O, et al.: Effects of the dual endothelin-receptor antagonist bosentan in patients with pulmonary hypertension: a randomised placebo-controlled study. Lancet. 358: 1119-1123, 2001.

15) Rubin LJ, Badesch DB, Barst RJ, et al.: Bosentan therapy for pulmonary arterial hypertension. N Engl J Med. 346: 896-903, 2002.

16) Galie N, Rubin Lj, Hoeper M, et al.: Treatment of patients with mildly symptomatic pulmonary arterial hypertension with bosentan (EARLY study): a double-blind, randomised controlled trial. Lancet. 371: 2093-2100, 2008.

17) Badesch DB, Abman SH, Simonneau G, et al.: Medical therapy for pulmonary arterial hypertension: updated ACCP evidence-based clinical practice guidelines. Chest. 131: 1917-1928, 2007.

18) Murphey LM, Hood EH: Bosentan and warfarin interaction. Ann Pharmacother. 37: 10281031, 2003.

19) Galiè N, Olschewski H, Oudiz RJ, et al.: Ambrisentan in Pulmonary Arterial Hypertension, Randomized, Double-Blind, Placebo-Controlled, Multicenter, Efficacy Studies (ARIES) Group. Circulation. 117: 2966-2968, 2008.

20) Barst RJ, Langleben D, Badesch D, et al.: Treatment of pulmonary arterial hypertension with the selective endothelin-A receptor antagonist sitaxsentan. J Am Coll Cardiol. 47: 20492056, 2006.

21) Abrams D, Schulze-Neick I, Magee AG: Sil- denafil as a selective pulmonary vasodilator in childhood primary pulmonary hypertension. Heart. 84: E4, 2000.

22) Jackson G, Benjamin N, Jackson N, et al.: Effects of sildenafil citrate on human hemodynamics. Am J Cardiol. 83: 13C-20C, 1999.

23) Galie N, Ghofrani HA, Torbicki A, et al.: Sildenafil Use in Pulmonary Arterial Hypertension (SUPER) Study Group. Sildenafil citrate therapy for pulmonary arterial hypertension. $N$ Engl J Med. 353: 2148-2157, 2005.

24) Mathai SC, Girgis RE, Fisher MR, et al.: Addition of sildenafil to bosentan monotherapy in pulmonary arterial hypertension. Eur Respir J. 29: 469-475, 2007.

25) Paul GA, Gibbs JS, Boobis AR, et al.: Bosentan decreases the plasma concentration of sildenafil when coprescribed in pulmonary hypertension. $\mathrm{Br} J$ Clin Pharmacol. 60: 107-112, 2005.

26) Kamata $Y$, Iwamoto M, Minota S. Consecutive use of sildenafil and bosentan for the treatment of pulmonary arterial hypertension associated with collagen vascular disease: sildenafil as reliever and bosentan as controller. Lupus. 16: 901-903, 2007.

27) Cote RH. Characteristics of photoreceptor PDE (PDE6): similarities and differences to PDE5. Int J Impot Res. 16: S28-33, 2004.

28）西 征二：勃起障害 (Erectile Dysfunction, ED）診療の経験と新しい展開. 臨床と研究. 85: 456-462, 2008.

29) Corbin JD, Francis SH: Pharmacology of phosphodiesterase-5 inhibitors. Int J Clin Pract. 56: 453-459, 2002.

30）瀬底正吾, 大矢俊雄, 渡邉郁緒, 藤川慶太 : 日本人高齢および中高年男性を対象とした， 塩酸バルデナフィル投与時の網膜電位検査 および Farnsworth-Munsell-100hue 試験を用 いた網膜機能の検討. Diabetes Frontier. 19: 113-120, 2008.

31) Padma-Nathan H, Schulman C: Comparative selectivity profiles of tadalafil, sildenafil, and valdenafil using an in vitro phosphodiesterase activity assay. Int J Impot Res. 14: S20-S32, 2002.

32）西間木友衛，ほか.：膠原病に打ける肺高血压 症の治療アンケート調査一最終集計報告一. 厚生省特定疾患「混合性結合組織病調査研究 班」昭和 62 年度研究報告書. 42-44, 1988 . 
33）川合基司 : 静注用フローラン市販後調查結果 より（第 5 報). Prog. Med. 28：486-492, 2008.

34) Sitbon O, Humbert M, Nunes H, et al.: Long- term intravenous epoprostenol infusion in primary pulmonary hypertension: prognostic factors and survival. J Am Coll Cardiol. 40: 780$788,2002$. 